\title{
Editorial Winter 2013
}

\author{
Heather J. Hoag • Maurits Ertsen
}

Published online: 30 November 2013

(C) Springer Science+Business Media Dordrecht 2013

In late June 2013, water scholars from over 20 countries converged upon the Pierresvives archives of Herault in Montpellier, France, for the 8th conference of the International Water History Association. While the conference program revealed the geographical, chronological, methodological, and topical diversity of the field of water history, a central theme of the conference was that of water governance and administration. From a preconference trip to the village of Montady where a local farmers' association continues to control and maintain the irrigation system to a visit to the Roman aqueduct at Pont du Gard, participants were reminded of the various scales and approaches to water provision and control. How humans have attempted to develop, control, and distribute water resources has been linked directly to environmental conditions, population needs, and governmental and legal institutions. But what are the environmental, social, political, and economic implications of these efforts? How might an understanding of past approaches to water management contribute to better policy today?

The papers in this issue of Water History showcase both the different levels of water administration (affected communities, municipal authorities, private companies, and regional and national governments) and the different sources available to water historians interested in this topic (archeological sources, historical maps and visual representations, official and private archives).

The first three papers highlight the interaction of a local waterscape with regional authorities. Hector A. Orengo and Carme Miró contribute to the literature on water control and administration within the Roman Empire. Using archeological and topographical data, they reexamine the urban water supply of Barcino (modern-day Barcelona). Their detailed reconstruction of the city's water system challenges previous scholarship that posited the existence of multiple aqueducts; rather they argue that the water supply derived from one aqueduct (Montcada).

H. J. Hoag (ه)

University of San Francisco, San Francisco, CA, USA

e-mail: hjhoag@usfca.edu

M. Ertsen

Delft University of Technology, Delft, The Netherlands 
In his paper on the history of floods along Hungary's Raba River during the seventeenth century, András Vadas draws upon the private letters of landed elite to show how people experienced and then responded to the river's floods. Between 1600 and 1658, over 3,000 letters were sent to the Batthyany family of the market town of Kormend. Vadas argues such private letters are vital resources historians can use to understand the changing flood frequency in Early Modern Hungary as well as the region's environmental history more broadly.

Darren Stewart Crook examines the role of maps in reconstructing the water control and farming systems of China's Miju River during the nineteenth century. After providing a detailed analysis of a twelve woodblock map of the river, he illustrates both its value to the planning and implementation of water control projects as well as its limitations. While the map shows that "the rural inhabitants of Dengchuan lived in this map," such maps can also conceal the complexity of relations and resource use and need to be read alongside the existing written sources.

Both rural and urban residents were not alone in their concern over their water supplies. During the nineteenth century, municipal, regional, and national governments became increasingly concerned with the provision of adequate water supplies for sanitation, public health, and industrial purposes. The second set of papers examine how such concerns brought government authorities into both conflict and cooperation with private companies. Judith Thornton and Peter Pearson explore this municipal-private relationship through an examination of the Bristol Water Works Company (UK). Between 1846 and 1875, the municipal authorities were pragmatic in their approach to water provision in the city, allowing the company relative autonomy. However, following 1875 and the turn to public ownership of water companies, this relationship became more contentious. Thornton and Pearson provide a case study of the effects of the shift to greater governmental control of Britain's water sector in Bristol.

In Britain's colonies, business interests and government also shared a concern for the management and distribution of water resources. Peter Davies and Susan Lawrence integrate documentary and archeological sources to analyze how miners and government officials on Australia's goldfields (re)valued water during the nineteenth century. As miners constructed dams and races to control the water needed to work the mines, they not only changed the landscape but also necessitated the need for new legal codes.

Finally, Eva Jakobsson takes a long view of the development of legislation related to drainage ditches in Sweden between 1200 and 1900. Based on an analysis of legal codes and laws, she shows how draining the land for agricultural and later industrial purposes necessitated a legal framework that allowed the state to regulate the construction, maintenance, and control of ditches.

Together these papers provide an introduction to the myriad ways individuals, government authorities, and private companies sought to stabilize and benefit from their water resources. Who had power to determine the uses of and access to water shifted as demand for stable water resources increased and interpretations of the role of government authorities in administering a nation's water resources shifted. 